\title{
Niesamowite dramaty Stefana Grabińskiego
}

[rec. Stefan Grabiński, Dramaty, opr. i red. M. Byrska, M. Skrok, D. Kryj, wstęp R. Sokoloski, Lublin: Wydawnictwo Norbertinum, Lublin 2016, ss. 464]

Streszczenie: Prezentowany artykuł jest recenzją pierwszego na polskim rynku wydawniczym kompletnego zbioru dramatów Stefana Grabińskiego. W Dramatach redaktorki zaprezentowały zachowane utwory sceniczne autora Demona ruchu, cenionego do tej pory za swą twórczość nowelistyczną. Autor recenzji podkreśla wysiłek włożony w pracę edytorską, ale jednocześnie wskazuje dość istotne wady zbioru: brak szczegółowego opracowania poszczególnych tekstów oraz odniesienia ich do biografii pisarza, brak rysu historycznego i szerszego kontekstu literackiego. Autor artykułu podkreśla również, że w pracy zabrakło obszernego wstępu, który zachęciłby czytelnika do zapoznania się z zapomnianą twórczością dramatyczną Grabińskiego.

Słowa-klucze: recenzja, Grabiński, dramaty, niesamowitość

\footnotetext{
Wojciech Kalinowski - doktor nauk humanistycznych (literaturoznawstwo); polonista i anglista; współpracownik Wydziału Filologicznego Uniwersytetu w Białymstoku; autor monografii Hypnos fiction. Nowelistyka Stefana Grabińskiego (Białystok 2016).
} 


\section{Weird dramatic works of Stefan Grabinski}

Summary: This text is a review of the first complete compilation of dramas by Stefan Grabiński that appeared on the Polish publishing market. In Dramaty three authors represent surviving texts by the author of The Motion Demon who was until now recognized mostly as a short story writer rather than a novelist or a playwright. The author of this review points out major flaws of this compilation: the lack of detailed coverage of specific texts and lack of references to Grabiński's biography, history of literature and literary context.

Key words: review, Grabinski, dramatic works, weird fiction

Dramaty Stefana Grabińskiego z wprowadzeniem Richarda Sokoloskiego ${ }^{1}$ ukazały się w 2016 roku w Lublinie nakładem Wydawnictwa Norbertinum staraniem Katedry Tekstologii i Edytorstwa na Katolickim Uniwersytecie Lubelskim Jana Pawła II w serii Debiuty Edytorskie².

Opracowanie zawiera cztery części: krótkie słowo wstępne, w którym Richard Sokoloski wprowadza czytelnika w materię badawczą i przywołuje sylwetkę pisarza, zasadniczą część tekstu, na którą składają się dramaty: Ciemne sity (Willa nad morzem), Zaduszki (tworzą go trzy jednoaktówki³: Sen Krysty, Strzygoń, W Dzień Zaduszny), Manowiec oraz aneks, w którym przywołany zostaje dramat Larwy, będący pierwotną, uproszczoną wersją Manowca. Całość zamyka kilkunastostronicowa refleksja Dramaty Stefana Grabińskiego

1 Richard Allan Sokoloski (ur. 1951), profesor, pracownik naukowy Univeristy of Ottawa w katedrze Modern Languages and Literatures, znany głównie z pracy translatorskiej. Zob. T. Różewicz, Forms in relief: and other works, thum. i wstęp R. Sokoloski, Nowy Jork, Ottawa 1994; F. Przyłubski, Wspomnienie o Januszu Różewiczu, oprac., tłum. i wstęp R. Sokoloski, Ottawa 2000.

2 W tej serii ukazało się wcześniej opracowanie: Parabole, S. Grędziński, wprowadzenie J. F. Fert, redakcja, posłowie oraz komentarz edytorski M. Piech, Lublin 2016.

3 Nie udało się do dnia dzisiejszego ustalić ostatecznej kolejności części tej trylogii, zob. M. Byrska, M. Skrok, D. Kryj, Dramaty Stefana Grabińskiego jako problem wydawniczy, [w:] S. Grabiński, Dramaty, Lublin 2016, s. 464; A. Hutnikiewicz, Twórczość literacka Stefana Grabińskiego, Torun 1956, s. 84. 
jako problem wydawniczy autorstwa Magdaleny Byrskiej, Marleny Skrok oraz Doroty Kryj, w którym zawarto namysł badawczy, towarzyszący pionierskiej edycji niewydanych dotąd tekstów dramatycznych Grabińskiego, opisano w zarysie twórczość dramatyczną autora Demona ruchu $u^{4}$, wskazano podstawy wydań, z których korzystano podczas pracy badawczej, oraz omówiono zasady opracowania poszczególnych tekstów, jak i dokonano pewnego uzasadnienia przyjętej kompozycji i układu treści. Całość zamknięto w obszernej, liczącej bez mała ponad 450 stron publikacji, utrzymanej w jaskrawej, ciemnoróżowej stylistyce.

Na początku warto zauważyć, że omawiana pozycja jest książką bardzo długo wyczekiwaną przez miłośników tematów niesamowitych, a więc i pisarstwa Stefana Grabińskiego. Ten pisarz okresu Dwudziestolecia zapisał się w historii polskiej literatury jako twórca nowego na gruncie polskim nurtu nowelistyki niesamowitej, która przyniosła pisarzowi niesłabnącą popularność. Nazywany polskim Edgarem Allanem Poe ${ }^{5}$, został Grabiński zapamiętany nie tylko jako wyśmienity nowelista, ale również sprawny powieściopisarz, teoretyk literatury, znawca sztuki i filozofii, nauczyciel. Ale istnieje jeszcze inny, mniej znany, wręcz całkowicie zbywany milczeniem obszar jego twórczości artystycznej - obszar ekspresji dramatycznej. Scena wydawała się pisarzowi niewyzyskanym należycie do tej pory obszarem ekspresji twórczej, w którym - przy użyciu pionierskich technik i idei - można ujawnić ducha „niesamowitości" - stworzyć podwaliny dramatu fantastycznego, przez samego Grabińskiego opatrzonego nazwą dramatu metempsychicznego. Niestety, nie udało się Grabińskiemu urzeczywistnić swoich zamiarów.

W stowie wstepnym Richard Sokoloski przypomina, że Grabiński ma dzisiaj status , ,...] reprezentanta nowego nurtu szeroko rozumianej fantastyki, klasyka polskiej literatury grozy, horroru i literatury niesamowitej"4, ale jed-

4 Stefan Grabiński jest autorem ponad 70 nowel, 4 powieści oraz kilkunastu recenzji i artykułów krytyczno-literackich, zob. W. Kalinowski, Wstęp, [w:] tegoż, Hypnos fiction. Nowelistyka Stefana Grabińskiego, Białystok 2016, s. 17.

5 Związek twórczości Stefana Grabińskiego z pisarstwem Edgara Allana Poe oraz Howarda Phillipsa Lovecrafta jest niezwykle ciekawy, zob. W. Kalinowski, Hypnos fiction w kontekście nowelistyki Edgara Allana Poego i Howarda Phillipsa Lovecrafta, [w:] tegoż, Hypnos fiction..., s. 233-274.

6 R. Sokoloski, Słowo wstępne, [w:] S. Grabiński, Dramaty, Lublin 2016, s. 5. 
nocześnie nobilituje autora Demona ruchu, umieszczając go pośród takich nazwisk, jak: Norwid, Witkiewicz czy Schulz . Podkreśla również fakt, że współczesna popularność Grabińskiego wynika z pewnej analogii. Odczytamy ją, kiedy przyjrzymy się traumie cywilizacyjnej, ogarniającej społeczeństwa europejskie po I wojnie światowej i skonfrontujemy ją z pewną „depresją”, załamaniem światopoglądowym społeczeństw XXI wieku ${ }^{8}$. Sokoloski wskazuje również, że Grabiński swój sprzeciw wobec niezrozumiałości i tajemnicy rzeczywistości, w której żyje współczesny człowiek, artykułuje w języku ,[...] przerażenia i grozy, w języku równoważonym pragnieniem zrozumienia rzeczywistości przez odwołanie się do porządku nieempirycznego, wyłaniającego się z odmętów żywiołu irracjonalnego, nadprzyrodzonego"9.

Więcej o Grabińskim jako dramatopisarzu ujawniają w kończącym zbiór referacie trzy wspomniane autorki, którym zawdzięczamy opracowanie i wydanie zbioru ${ }^{10}$. Jak czytamy: ,[...] twórczość sceniczna tego pisarza stanowi prawie zupełnie nieznaną część spuścizny [...]"11, co ma wynikać z faktu, że wszystkie teksty pozostawały w rękopisie, a więc były niedostępne czytelnikowi. Drugim, równie istotnym powodem było funkcjonujące w środowisku polonistycznym przekonanie, że ,[...] dramaturgia autora [...] jest sztuką niskich lotów, której nie warto poświęcać uwagi"12.

W dalszej części tego tekstu odnajdziemy ponadto: krótką biografię Grabińskiego w kontekście jego dramatopisarstwa (część Grabiński jako dramaturg) oraz głosy krytyczne (w większości negatywne), które towarzyszyły publikacjom poszczególnych dramatów. W części zatytułowanej Podstawy wydań znajdziemy z kolei szczegółowe informacje na temat zachowanych pierwodruków, skanów, egzemplarzy teatralnych i rękopisów, dzięki którym niniejsza pozycja mogła powstać. Znajdziemy tu również komentarz wyjaśniający przyjęty układ tekstów, przedstawionych odbiorcy w układzie chronologicznym (część Kompozycja publikacji). Artykuł zamyka część dotycząca zasad opraco-

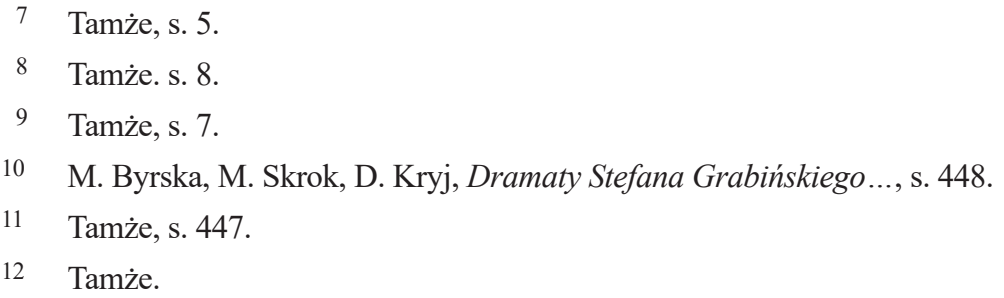


wania, problemów edytorskich, podziału obowiązków przy żmudnej analizie poszczególnych dzieł, a wreszcie - konieczności zaproponowania jednolitego układu edytorskiego: uporządkowania didaskaliów, szczegółów technicznych, modyfikacji zapisu, usunięć lub przesunięć w nazwach własnych, przypisach i podkreśleń. Poszczególne utwory zostały bowiem zmodernizowane pod względem ortografii i interpunkcji, przy jednoczesnym zachowaniu bogatego i wewnętrznie zróżnicowanego systemu interpunkcyjnego, zastosowany przez Grabińskiego w taki sposób, aby odnieść się z należytym respektem do koncepcji autorskich.

Omawiana edycja przedstawia w zasadzie pierwszy kompletny, kanoniczny zbiór utworów dramatycznych Stefana Grabińskiego. Pierwszy z przywołanych dramatów Ciemne siły z podtytułem Willa nad morzem w wydaniu książkowym ukazał się w 1921 roku. Publikację poprzedził udany debiut sztuki na deskach Teatru Małego w Warszawie, gdzie wystawiono ją przeszło 40 razy. Wątek treściowy pochodził z noweli pod tym samym tytułem i w największym skrócie przedstawia się następująco: ,[...] zazdrosny mąż posuwa się do zbrodni, aby wyeliminować pierwszą miłość swej żony. Zaprasza go na obiad i podaje zatrutą potrawę w dzień podróży morskiej rywala. Pasażerowie statku giną w katastrofie morskiej"13. Elementem fantastycznym, który determinuje poczynania głównych bohaterów staje się ksenonimia - „wymyślona przez samego Grabińskiego przypadłość, na mocy której jeden z bohaterów, bezwiednie zachowuje się jak ofiara, wraz z synkiem żony i jej kochankiem doprowadza do ujawnienia morderstwa"14. Oryginalna, niespotykana wcześniej formuła wypowiedzi scenicznej wywołała niejednorodne głosy krytyczne niestety - z przewagą głosów obojętnych lub nieprzychylnych. Również próba przekładu dramatu na inne języki europejskie nie zakończyła się sukcesem.

Kolejny dramat - Zaduszki - ukazał się zaledwie kilka miesięcy później. Była to trylogia dramatyczna, składająca się z trzech, niezwiązanych tematycznie jednoaktówek. Artur Hutnikiewicz w swojej monografii opisał je następująco:

[...] dwie pierwsze miały charakter teatru obrzędowego. Sen Krysty był jakby sceniczną ilustracją wiary w reinkarnację, odtwarzał w formie misteryjno-wido-

13 Tamże, s. 450.

14 Tamże. 
wiskowej moment przyoblekania się jaźni bezcielesnych w kształt materialny; Strzygoń nawiązywał do ludowej wiary w istnienie osób posiadających dwie dusze, z których jedna ochrzczona dostępują łaski zbawienia, a druga, pozbawiona błogosławieństwa chrztu, w nieustannej męce błąka się po śmierci ciała po świecie ${ }^{15}$.

Ostatnia z nich - W Dzień Zaduszny - przenosi odbiorcę w kręgi elity intelektualnej. Główną bohaterką jest wdowa „,...] rozdarta między wiernością wobec pamięci zmarłego męża a głębokim porywem serca ku [...] młodemu psychologowi, z którym połączył ją romans jeszcze za życia małżonka"16. Dramat opowiada o:

[...] konflikcie sumienia, konflikcie między powinnością a miłością, sprawiającym, że bohaterka popada w coraz głębsze rozstrojenie nerwowe, przejawiające się między innymi uczuciem stałej obecności zmarłego oraz przekonaniem o grożącej jej ze strony nieznanych mocy zemście. Jak się bowiem okazuje, pod wpływem szeregu zdarzeń początkowo zdających się zupełnie przypadkowymi, ale w końcu przybierających formę łańcucha przyczyn i skutków zadzierzgniętego przez bliżej nieokreślone siły irracjonalne, Janina jest odpowiedzialna za śmierć męża, któremu nie podała o oznaczonej porze leku ratującego życie ${ }^{17}$.

Ostatni z dramatów - Manowiec - ujrzał światło dzienne dopiero 6 lat później - w roku 1927. O tym utworze sam Grabiński wypowiedział się następująco: „Bohaterem jest lekarz psychiatra, który pada ofiarą swej niepohamowanej żądzy wdarcia się w dziedzinę tajników zaświatowych. Utwór ten, podobnie jak Willa nad morzem, wprowadza na scenę teatru żywioł metafantastyczny - jest nowym rodzajem dramatu, który nazwałbym dramatem metapsychicznym"18.

15 A. Hutnikiewicz, Twórczość literacka Stefana Grabińskiego, Toruń 1956, s. 84.

16 A. Mianecki, Folklor a fantastyka w trylogii dramatycznej „Zaduszki” Stefana Grabińskiego, [w:] Inspiracje ludowe w literaturach stowiańskich XI-XXI wieku, pod red. I. Rzepnikowskiej, Toruń 2009, s. 152.

17 Tamże, s. 153.

18 k.w. [K. Wierzyński], U Stefana Grabińskiego, „Lwowskie Wiadomości Muzyczne i Literackie" 1930, nr 7/8 (1 VII), s. 1-2 - cyt. za: Trzy wywiady ze Stefanem Grabińskim, wstęp i oprac. A. Mianecki, „Litteraria Copernicana” 2013, nr 1(11), s. 264. 
Dramat nie doczekał się premiery scenicznej, chociaż, jak podaje Adam Mianecki, wyznaczono obsadę i próby do przedstawienia trwały ${ }^{19}$.

W aneksie znajdziemy nadto Larwy, utwór Grabińskiego, który według autorów stanowi ,[...] wcześniejszą redakcję [Manowca - W.K.] tego utworu, redakcję bardzo ciekawą" ${ }^{20}$. Umieszczenie w jednym zbiorze dwóch w zasadzie identycznych tekstów wytłumaczone zostało pragnieniem ukazania rozwoju drogi twórczej autora Demona ruchu²1.

Należy jeszcze raz podkreślić, że omawiana publikacja jest długo wyczekiwanym wypełnieniem luki dotyczącej twórczości dramatycznej Grabińskiego. Do tej pory na rynku wydawniczym próżno szukać dramatów autora Księgi ognia. Zbywane i przesuwane na margines dokonań literackich utwory sceniczne nie doczekały się należytego, wyczerpującego wznowienia i opracowania. Niestety, tę pustkę omawiany tekst wypełnia w sposób nie do końca rzetelny, nie zawsze zgodnie z prawidłami krytycznej analizy tekstów.

Ratując w tej publikacji to, co najlepsze, bez wątpienia wskażemy same teksty. Dramaty dają możliwość zetknięcia się po raz pierwszy z utworami do tej pory praktycznie nieosiągalnymi. Trzy młode badaczki wykonały żmudną i trudną pracę edytorską, gdyż wyraźnie podkreślają, że „karty manuskryptów pełne są skreśleń, sporządzonych kredkami dopisków i wielu innych sygnałów nie tylko komplikujących samą lekturę, ale także, co ważniejsze, możliwość ustalenia jedynej, właściwej wersji danej sztuki”22. Rzetelność tej pracy edytorskiej zauważymy podczas lektury - teksty zostały uporządkowane, „uwspółcześnione”, aby ułatwić odbiór treści. Wszystkie modernizacje (bez wątpienia słuszne) mogą jednak budzić pewne obawy o „zgodność z oryginałem". Wiemy, jak wielką wagę przykładał sam Grabiński do precyzji wypowiedzi. Musimy wierzyć autorkom, że obrały właściwą metodę prezentacji, ,[...] ingerując w tekst jak najrzadziej i respektując, w miarę możliwości, wolę autora"23.

19 Z korespondencji Stefana Grabińskiego, podał do druku A. Mianecki, „Rocznik Przemyski” 2010, t. 46, z. 3, Literatura i Język, s. 113.

20 Dramaty Stefana Grabińskiego..., s. 464.

21 Tamże.

22 Tamże, s. 465.

23 Tamże, s. 465. 
Przyglądając się zbiorowi od strony formalnej i układu poszczególnych jego części od razu zauważymy, że tekst narusza pewne ustalone zwyczaje edytorskie. Cierpi również z powodu minimalizmu. Wstęp skompresowany zostaje zaledwie do słowa wstępnego, a zamieszczony na końcu kilkunastostronicowy artykuł, który ma wyjaśniać zasady wydania, ma aż trzech autorów. Nowe Dramaty Grabińskiego zostają w pewnym sensie zawieszone w próżni, nie wiadomo w zasadzie, kto za dzieło odpowiada, kto jest głównym pomysłodawcą, inicjatorem powstania zbioru.

Brakuje tej pracy rzeczowego przyjrzenia się treści prezentowanych dramatów i wskazania ich wartości. Autorzy ograniczają się do przygotowania samych tekstów i ich opracowania edytorskiego, ale - czego oczekiwalibyśmy od pionierskiej (przecież!) pracy - nie są one w żaden sposób omówione, opatrzone przypisami, umieszczone w szerszym kontekście twórczości artystycznej Grabińskiego. W żadnym momencie nie słyszymy głosu zachęcającego do ich lektury, co więcej, autorzy zarówno w Stowie wstępnym, jak i w zakończeniu przywołują Grabińskiego częściej przez pryzmat jego nowelistyki aniżeli dramatów. Wydaje się to niewybaczalnym błędem. Takim samym niedopatrzeniem i ograniczeniem jest brak bibliografii, indeksów, a więc elementów, którymi powinna charakteryzować się solidna, odkrywcza praca edytorska.

Pojawić się więc musi w tym miejscu pytanie w zasadzie najistotniejsze: do kogo kierowana jest niniejsza praca? Jak przecież wiadomo, Grabiński jest ceniony za swoją nowelistykę i niestety - po lekturze Dramatów - takim $\mathrm{w}$ dalszym ciągu pozostanie. Pozbawione autorskiego komentarza i szerokiego odniesienia do poglądów religijnych, światopoglądowych, historycznych i filozoficznych Grabińskiego, oderwane od nowel, powieści, tekstów teoretyczno-literackich dla przeciętnego miłośnika sztuki dramatycznej Dramaty nie przedstawią większej wartości, tym bardziej, że sami autorzy kilkukrotnie podkreślają ich wtórność i drugorzędność wobec nowel.

Jeżeli natomiast ograniczymy grono odbiorców do znawców tematów niesamowitych i twórczości Grabińskiego - ich również czeka niechybny zawód. Dostają do ręki upragniony tekst, ale nic ponadto. Dramat metempsychiczny jest dramatem wyjątkowym, jest próbą wcielenia idei niesamowitości w ramy sceniczne. Czy udanym? - opinie są podzielone, ale to bez wątpienia wymaga szerokiego komentarza. Zabrakło tu jednak miejsca na tego typu dopowiedze- 
nia i rozważania. Może lepiej byłoby podzielić cały dorobek dramatyczny na części, opublikować teksty osobno, zaprosić do współpracy znawców tematu, historyków literatury, językoznawców, opatrzyć całość obszernym komentarzem, wyjaśniającym zawiłości myśli Grabińskiego? Bez wątpienia takie działanie wpłynęłoby pozytywnie na odbiór dramatów twórcy - a przecież taki cel (miejmy nadzieję) przyświecał autorom edycji.

Podsumowując, należy stwierdzić, że omawiany zbiór dramatów wywołuje mieszane odczucia z punktu widzenia sztuki edytorskiej. Można odnieść wrażenie, że dostaliśmy do ręki diament, który nie został oszlifowany. Dramatyczne teksty Grabińskiego są niezbędnym uzupełnieniem całości jego dorobku literackiego. Bez dociekliwej, kompletnej eksploracji tych obszarów wizerunek twórcy osobliwego - a takim bez wątpienia był Grabiński - nigdy nie będzie kompletny.

\section{Bibliografia}

Byrska M., Skrok M., Kryj D., Dramaty Stefana Grabińskiego jako problem wydawniczy, [w:] S. Grabiński, Dramaty, Lublin 2016, s. 464.

Grędziński S., Parabole, wprowadzenie J. F. Fert, redakcja, posłowie oraz komentarz edytorski M. Piech, Lublin 2016.

Hutnikiewicz A., Twórczość literacka Stefana Grabińskiego, Toruń 1956, s. 84.

Kalinowski W., Hypnos fiction w kontekście nowelistyki Edgara Allana Poego i Howarda Phillipsa Lovecrafta, [w:] tegoż, Hypnos fiction..., s. 233-274.

Kalinowski W., Wstęp, [w:] tegoż, Hypnos fiction. Nowelistyka Stefana Grabińskiego, Białystok 2016, s. 17.

Mianecki K., Folklor a fantastyka w trylogii dramatycznej „Zaduszki” Stefana Grabińskiego, [w:] Inspiracje ludowe w literaturach słowiańskich XI-XXI wieku, pod red. I. Rzepnikowskiej, Toruń 2009, s. 152.

Przyłubski F., Wspomnienie o Januszu Różewiczu, oprac., tłum. i wstęp R. Sokoloski, Ottawa 2000.

Różewicz T., Forms in relief: and other works, tłum. i wstęp R. Sokoloski, Nowy Jork, Ottawa 1994.

Sokoloski R., Słowo wstępne, [w:] S. Grabiński, Dramaty, Lublin 2016, s. 5. 
k.w. [Wierzyński K.], U Stefana Grabińskiego, „Lwowskie Wiadomości Muzyczne i Literackie" 1930, nr 7/8 (1 VII), s. 1-2 - cyt. za: Trzy wywiady ze Stefanem Grabińskim, wstęp i oprac. A. Mianecki, „Litteraria Copernicana” 2013, nr 1(11), S. 264.

Z korespondencji Stefana Grabińskiego, podał do druku A. Mianecki, „Rocznik Przemyski" 2010, t. 46, z. 3, Literatura i Język, s. 113. 